6th International Conference on Industrial Engineering and Industrial Management.

XVI Congreso de Ingeniería de Organización. Vigo, July 18-20, 2012

\title{
Safety management models in manufacturing companies.
}

\section{Carrillo JA $\mathbf{J}^{1}$, Guadix $\mathrm{J}^{2}$, Onieva $\mathrm{L}^{3}$}

\begin{abstract}
In Spain, companies can decide how to manage safety. Although most safety activities are mandatory, the management model can be decided in some extend by each company. Not all models have the same effectiveness according to their preventive practices and injury rates. This study applies a discrimination model in order to determine which reasons and circumstances make a company adopt a certain safety model or a safety management system. Results can be used in public promotion programs oriented to convince managers of the benefits of implementing safety management systems with internal preventive resources instead of subcontracting an external preventive service.
\end{abstract}

Keywords: Safety Management, Manufacturing Sector, Organizational Factors, Preventive Services.

\subsection{Introduction}

In Spain, as part of the European Union, there are some mandatory elements of safety management according to the Framework Directive 89/391/EEC on the in-

\footnotetext{
${ }^{1}$ Jesús Antonio Carrillo Castrillo $(\bowtie)$

Dirección General de Seguridad y Salud Laboral, Avda. Hytasa, 14 P-1, 41006 Sevilla, Spain e-mail: jacarcas@gmail.com

${ }^{2}$ José Guadix

Grupo de Investigación de Ingeniería de Organización, Universidad de Sevilla. Camino de los Descubrimientos s/n Isla de la Cartuja 41092 Sevilla, Spain e-mail:guadix@esi.us.es

${ }^{3}$ Luis Onieva Giménez

Grupo de Investigación de Ingeniería de Organización, Universidad de Sevilla. Camino de los Descubrimientos s/n Isla de la Cartuja 41092 Sevilla, Spain e-mail: onieva@us.es
} 
troduction of measures to encourage improvements in the safety and health of workers at work.

A management system is a network of interrelated elements. These elements include responsibilities, authorities, relationships, functions, activities, processes, practices, procedures, and resources. A management system uses these elements to establish policies, plans, programs, and objectives and to develop ways of implementing these policies, plans, and programs, and achieving these objectives (Cagno et al. 2011).

Previous surveys have been able to find evidence of the effect of adopting a safety management system (Bottani et al. 2009), as an evaluation of factors identified as performance in main attitudes to do active preventive activities (such as defining and communicating goals, updating risk, assessing and evaluating risks and training of workers).

However, safety management is more likely related to actual practices, roles and functions and it is an antecedent of safety climate as the system impacts employees' attitude and behaviour (Fernández-Muñiz et al. 2009). This safety climate is an intermediate outcome more useful to evaluate safety management than injury rates.

\subsection{Conceptual Model}

In Spain, companies can decide how to manage safety. Although most safety activities are mandatory ${ }^{4}$, the management model can be decided in some extend by each company. Some companies decide to implement safety management standards as OSHAS $18001^{5}$. Understanding the managers motivations (Huang et al. 2011) can help to develop more effective promotion programs of those safety models and systems considered more suitable.

Another important company's decision is how technical assessment and preventive activities are assigned. According to Spanish regulations ${ }^{6}$, safety assessment and preventive activities can be organized both with internal resources or subcontracting an external preventive service. There are many possibilities depending on how many activities are subcontracted.

Our interest is to research about the factors that contributes in this important decision and how the different safety management models influence the development of safety activities and resources.

\footnotetext{
4 Ley 31/1995 de Prevención de Riesgos Laborales, BOE número 269 de 10/11/1995, páginas 32590 a 32611. http://www.boe.es. Accessed 1 February 2012.

${ }^{5}$ OHSAS 18001:2007 "Occupational health and safety management systems. Requirements". Published by BSI, UK's National Standards Body.

6 Real Decreto 39/1997 por el que se aprueba el Reglamento de Servicios de Prevención. BOE número 27 de 31/01/1997, páginas 3031 a 3045. http://www.boe.es. Accessed 1 February 2012.
} 
Safety management model can be chosen using four basic archetypes. Although a range of mixed solutions are possible, we assigned according to managers answers to each company only one model.

Models are related to what specific preventive resources are available. The first of those models is based in a personal assumption by the owner. This is only possible if the company has less than nine workers and there is no high hazard. In this model the main strength is the strong alignment of safety and management.

The second possible model is to have specific workers with safety assignment. Although this possibility can be found in the other models, here we include those companies who consider this resource as the main preventive mean.

The third possible model is to subcontract an external preventive service. This possibility is associated to a lack of integration of safety in the general management. There are also threats of lack of quality in some services. Again these subcontracts can be found in the rest of models but here we include those companies that consider this externalization as the main resource for prevention.

The last possibility is to have an internal preventive service with specialized safety advisors in the company. In this model there is still a strong integration of safety issues. We include in this model those preventive services that are shared by a set of companies in the same sector or industrial site. This model is only mandatory for big companies and it is considered by safety experts as the best in terms of integration and quality (Carrillo and Onieva 2011).

A lot has been written about the advantages of certain safety management models whereas no scientific evidence has been published. Our hypothesis is that there are predictor factors that explain why companies chose one safety management model. Understanding this process can help to design public programs in case it is considered necessary to promote certain models.

Also we researched which factors influence implementing a safety management system -SMS-.

There is a lot of evidence of the importance of organizational factors in safety and their relationship with injury rates (Arocena et al. 2008) (Geldart et al. 2010) (Carrillo and Onieva 2012). Safety models have influence on those organizational factors too.

\subsection{Safety models and systems: the benefits}

It is necessary to know which benefits and which advantages can be expected depending on the safety model chosen. In the survey there is information about preventive activities achieved.

In order to understand how safety management model and safety management systems affect the development of preventive activities we have calculated the average number of activities (see Table 1), stratifying by company size (Sorensen et 
al. 2007). These indicators of preventive activities are intermediate indicators of safety management performance (Sgorou et al. 2010) (Øien et al. 2011).

In spite of the limitations of injury rates as safety indicator, we have also compute injury rates for the different safety management models (see Table 2).

Table 1. Preventive practices and safety models.

\begin{tabular}{cccccccc}
\hline $\begin{array}{c}\text { Company } \\
\text { Size }^{1}\end{array}$ & $\begin{array}{c}\text { Preventive } \\
\text { activities }^{2}\end{array}$ & $\begin{array}{c}\text { Assumed } \\
\text { by owner }\end{array}$ & $\begin{array}{c}\text { Worker } \\
\text { assigned }\end{array}$ & $\begin{array}{c}\text { External } \\
\text { prev.service }\end{array}$ & $\begin{array}{c}\text { Internal } \\
\text { prev.service }\end{array}$ & $\begin{array}{c}\text { Without } \\
\text { SMS }\end{array}$ & $\begin{array}{c}\text { With } \\
\text { SMS }\end{array}$ \\
\hline \multirow{3}{*}{ Micro } & Practices & 1,35 & 3,11 & 3,40 & 2,13 & 1,92 & 3,97 \\
& Assessments & 2,00 & 3,42 & 3,81 & 1,63 & 2,81 & 3,87 \\
& Measure & 1,42 & 1,32 & 1,99 & 1,38 & 1,54 & 2,07 \\
\hline \multirow{3}{*}{ Small } & Practices & - & 5,38 & 3,89 & 6,80 & 3,33 & 4,80 \\
& Assessments & - & 4,12 & 3,44 & 2,17 & 2,88 & 4,16 \\
& Measures & - & 2,31 & 2,00 & 2,00 & 1,65 & 2,28 \\
\hline \multirow{3}{*}{ Medium } & Practices & - & 6,20 & 5,61 & 4,71 & 4,36 & 5,86 \\
& Assessments & - & 5,55 & 4,75 & 4,29 & 4,82 & 4,89 \\
& Measures & - & 3,82 & 2,89 & 3,71 & 3,45 & 3,05 \\
\hline \multirow{3}{*}{ Big } & Practices & - & 7,00 & 6,63 & 8,40 & 2,00 & 7,53 \\
& Assessments & - & 5,40 & 5,50 & 6,00 & 8,00 & 5,47 \\
& Measures & - & 4,40 & 4,75 & 6,00 & 8,00 & 4,82 \\
\hline
\end{tabular}

${ }^{1}$ Size is determined by the number of workers.

${ }^{2}$ Average number of preventive

Table 2. Injury rates and safety models.

\begin{tabular}{ccccccc}
\hline $\begin{array}{c}\text { Company } \\
\text { size }\end{array}$ & $\begin{array}{c}\text { Assumed by } \\
\text { owner }\end{array}$ & $\begin{array}{c}\text { Worker } \\
\text { assigned }\end{array}$ & $\begin{array}{c}\text { External } \\
\text { prev.service }\end{array}$ & $\begin{array}{c}\text { Internal } \\
\text { prev.service }\end{array}$ & $\begin{array}{c}\text { Without } \\
\text { SMS }\end{array}$ & $\begin{array}{c}\text { With } \\
\text { SMS }\end{array}$ \\
\hline Micro & 219,78 & 258,33 & 365,73 & 187,50 & 335,05 & 257,86 \\
Small & 90,17 & 192,51 & 141,84 & - & 144,30 & 160,97 \\
Medium & - & 217,68 & 137,49 & 71,18 & 161,65 & 151,07 \\
Big & - & 66,21 & 314,40 & 55,93 & - & 162,40 \\
\hline
\end{tabular}

\subsection{Data}

The First Andalusian Safety Management Survey gathered data from a sample of companies selected randomly. All companies were visited by a professional interviewer. The total number of manufacturing companies was estimated at 30,296.

The number of companies surveyed from the industrial sector is 682 , thus the expected error with $\mathrm{P}=\mathrm{Q}$ is $3.82 \%$. In terms of company size, big companies were underrepresented in the sample (Instituto Andaluz de Prevención de Riesgos Laborales, 2011). Industrial sector includes manufacturing activities, utilities and industrial outsourcing.

There are 503 cases from manufacturing companies available. As we are interested in the safety management models we decided only to considerer those cases with all questions about safety management fulfilled. With this criterion, there are 
413 cases with information about their safety models and possible predictors (see Table 3 and 4).

According to previous studies there are some characteristics of a company identified in this survey that can determine a safety management model: company and establishment size, number of years of the company and main activity.

Other important factors gathered are related to safety management complexity such as how likely safety accidents are, working in shifts, subcontracting, renewing machinery or certain high hazardous tasks.

Table 3. Safety management model predictors: percentage of companies of each model.

\begin{tabular}{|c|c|c|c|c|c|c|}
\hline Variable & $\begin{array}{l}\text { Anova } \\
\text { (sig.) }\end{array}$ & Categories & $\begin{array}{l}\text { Assumed } \\
\text { by owner }\end{array}$ & $\begin{array}{l}\text { Worker } \\
\text { assigned }\end{array}$ & $\begin{array}{c}\text { External } \\
\text { prev. service }\end{array}$ & $\begin{array}{c}\text { Internal } \\
\text { prev. service }\end{array}$ \\
\hline \multirow{4}{*}{ Activity } & \multirow{4}{*}{0,28} & Consumer prod. & $17 \%$ & $12 \%$ & $62 \%$ & $9 \%$ \\
\hline & & Chemical & $8 \%$ & $23 \%$ & $68 \%$ & $2 \%$ \\
\hline & & Metal & $17 \%$ & $11 \%$ & $64 \%$ & $7 \%$ \\
\hline & & Rest of manuf. & $14 \%$ & $18 \%$ & $66 \%$ & $2 \%$ \\
\hline \multirow{4}{*}{$\begin{array}{c}\text { Company size } \\
\text { (number of workers) }\end{array}$} & \multirow{4}{*}{0,00} & Micro (1-9) & $23 \%$ & $8 \%$ & $66 \%$ & $3 \%$ \\
\hline & & Small (10-49) & $9 \%$ & $21 \%$ & $66 \%$ & $5 \%$ \\
\hline & & Medium (50-249) & $4 \%$ & $23 \%$ & $58 \%$ & $15 \%$ \\
\hline & & $\operatorname{Big}(>250)$ & $0 \%$ & $28 \%$ & $44 \%$ & $28 \%$ \\
\hline \multirow{3}{*}{ Company years } & \multirow{3}{*}{0,31} & New $(<3)$ & $21 \%$ & $8 \%$ & $65 \%$ & $6 \%$ \\
\hline & & Young (3-10) & $18 \%$ & $15 \%$ & $63 \%$ & $4 \%$ \\
\hline & & Mature $(>10)$ & $13 \%$ & $16 \%$ & $64 \%$ & $7 \%$ \\
\hline \multirow{2}{*}{ Shifts } & \multirow{2}{*}{0,00} & No & $16 \%$ & $13 \%$ & $66 \%$ & $5 \%$ \\
\hline & & Yes & $4 \%$ & $43 \%$ & $26 \%$ & $26 \%$ \\
\hline \multirow{2}{*}{ Outsourcing workers } & \multirow{2}{*}{0,05} & No & $17 \%$ & $13 \%$ & $65 \%$ & $6 \%$ \\
\hline & & Yes & $11 \%$ & $24 \%$ & $57 \%$ & $9 \%$ \\
\hline \multirow{2}{*}{ Highly hazardous } & \multirow{2}{*}{0,02} & No & $18 \%$ & $14 \%$ & $61 \%$ & $6 \%$ \\
\hline & & Yes & $5 \%$ & $15 \%$ & $74 \%$ & $5 \%$ \\
\hline \multirow{2}{*}{ Safety management } & \multirow{2}{*}{0,00} & No & $26 \%$ & $12 \%$ & $57 \%$ & $5 \%$ \\
\hline & & Yes & $7 \%$ & $17 \%$ & $69 \%$ & $7 \%$ \\
\hline $\begin{array}{l}\text { Risk of traumatic } \\
\text { accidents }\end{array}$ & 0,08 & $\begin{array}{l}\text { No } \\
\text { Yes }\end{array}$ & & & & \\
\hline $\begin{array}{l}\text { Risk of musculo- } \\
\text { skeletal accidents }\end{array}$ & 0,00 & $\begin{array}{l}\text { No } \\
\text { Yes }\end{array}$ & & & & \\
\hline \multirow{2}{*}{$\begin{array}{c}\text { New machinery in last } \\
2 \text { years }\end{array}$} & \multirow{2}{*}{0,00} & 1 & $18 \%$ & $19 \%$ & $56 \%$ & $7 \%$ \\
\hline & & 2 & $13 \%$ & $8 \%$ & $73 \%$ & $5 \%$ \\
\hline \multirow{2}{*}{$\begin{array}{c}\text { Worker } \\
\text { representation }\end{array}$} & \multirow{2}{*}{0,00} & 0 & $19 \%$ & $6 \%$ & $72 \%$ & $3 \%$ \\
\hline & & 1 & $6 \%$ & $37 \%$ & $43 \%$ & $14 \%$ \\
\hline
\end{tabular}

Managers have also identified in the survey the company's strategies, company's opinion about safety regulations and company's motivation for safety commitment.

Finally, workers representation can influence in management the selection of safety management. Usually, worker representatives will demand internal resources instead of external ones. 
Most of discrimination factors are determined as survey responses and they are objective data. The rest of them are Liker scale subjective questions about company's strategies, motivations for safety and opinion about safety regulations.

Table 4. Safety management model predictors: average for each safety model.

\begin{tabular}{|c|c|c|c|c|c|}
\hline Group & Question & $\begin{array}{l}\text { Assumed } \\
\text { by owner }\end{array}$ & $\begin{array}{l}\text { Worker } \\
\text { assigned }\end{array}$ & $\begin{array}{c}\text { External } \\
\text { prev. service }\end{array}$ & $\begin{array}{c}\text { Internal } \\
\text { prev. service }\end{array}$ \\
\hline \multirow{5}{*}{ Strategies } & Reduce prod. costs & 3.66 & 4.07 & 3.32 & 3.50 \\
\hline & Improve safety & 3.92 & 4.74 & 3.74 & 4.88 \\
\hline & Improve image & 5.11 & 5.16 & 5.54 & 4.92 \\
\hline & Innovation & 7.00 & 6.89 & 6.87 & 6.92 \\
\hline & Sustainability & 8.11 & 8.10 & 7.57 & 7.92 \\
\hline \multirow{7}{*}{$\begin{array}{l}\text { Opinion about } \\
\text { safety } \\
\text { regulation }\end{array}$} & Difficult & 2.77 & 2.54 & 2.29 & 2.38 \\
\hline & Adequate & 2.60 & 2.36 & 2.32 & 2.35 \\
\hline & Complex & 2.83 & 2.64 & 2.38 & 2.38 \\
\hline & Profitable & 2.98 & 2.85 & 2.94 & 2.65 \\
\hline & For any activity & 2.98 & 2.93 & 2.75 & 2.62 \\
\hline & For any company's size & 3.11 & 2.87 & 2.97 & 2.73 \\
\hline & Effective & 2.71 & 2.79 & 2.45 & 2.58 \\
\hline \multirow{8}{*}{$\begin{array}{l}\text { Motivation } \\
\text { for safety }\end{array}$} & Comply & 1.86 & 1.70 & 1.87 & 1.23 \\
\hline & Fines & 1.52 & 0.74 & 0.95 & 1.12 \\
\hline & Petitions & 0.35 & 0.43 & 0.48 & 0.58 \\
\hline & Goodwill & 0.52 & 0.72 & 0.58 & 0.77 \\
\hline & Working Conditions & 1.05 & 1.13 & 1.01 & 1.23 \\
\hline & Economic & 0.18 & 0.34 & 0.30 & 0.15 \\
\hline & Better climate & 0.15 & 0.43 & 0.41 & 0.46 \\
\hline & Competitive & 0.28 & 0.79 & 0.45 & 0.00 \\
\hline
\end{tabular}

\subsection{Methodology and results: Discrimination analysis}

Although exploratory techniques can help to understand the different companies' profiles and their attitudes and safety management approaches, we have selected discrimination analysis because it provides the identification of a classification equation and deals with multivariate and multifactor nature of safety.

Discrimination analysis has been performed segmenting the cases using company size so four different sets of discrimination functions have been determined. SPSS v.18 was used. Both microdata and discrimination models are available upon request. All possible predictor's variables were included with step by step option, with Wilkins Lambda as method with intra-groups covariance matrixes (see Table 5 and 6). 


\subsection{Discussion}

According to the First Andalusian Safety Management Survey, when a company has a safety management system, the number of preventive activities implemented is higher than those without a system. Moreover, companies with internal preventive resources, such as workers assigned or internal preventive services, show higher number of preventive activities. These phenomena are more significant for micro and small companies, but less significant as the size of the company grows.

Companies can choose different safety management models. A discrimination analysis shows that there are variables that more likely can predict which model is chosen.

Table 5. Discrimination analysis results: Dependent variable "External Preventive Service".

\begin{tabular}{cccc}
\hline Company Size & Predictors & \% classification & St. Coef. (sig) \\
\hline & Worker Representation & & $0.74(<0.01)$ \\
Micro & Strategy is safety & & $0.34(0.04)$ \\
$(1-9)$ & Regulation is effective & $87.7 \%$ & $0.60(0.02)$ \\
& Regulation is difficult & & $-0.50(\mathrm{~ns})$ \\
& New machinery & & $-0.34(0.05)$ \\
\hline \multirow{3}{*}{ Small } & Number of different sites & & $0.41(0.06)$ \\
$(10-49)$ & Working in shifts & \multirow{2}{*}{$84.8 \%$} & $0.63(<0.01)$ \\
& Worker Representation & $0.67(<0.01)$ \\
& Strategy is sustainability & & $0.31(0.05)$ \\
& Risk of musculo-skeletal acc. & & $0.35(\mathrm{~ns})$ \\
\hline \multirow{3}{*}{ Medium } & Worker Representation & & $0.54(<0.01)$ \\
$(50-249)$ & Strategy is sustainability & \multirow{2}{*}{$81.3 \%$} & $0.49(0.02)$ \\
& Motivation is image & & $0.64(<0.01)$ \\
& Motivation is economic & & $0.54(<0.01)$ \\
\hline \multirow{2}{*}{ Big $(>249)$} & Regulation is profitable & \multirow{2}{*}{$83.3 \%$} & $0.90(0.02)$ \\
& New machinery & & $0.74(0.03)$ \\
\hline
\end{tabular}

Table 6. Discrimination analysis results: Dependent variable "Safety management system".

\begin{tabular}{cccc}
\hline Company Size & Predictors & \% classification & St. Coef. (sig) \\
\hline \multirow{2}{*}{ Micro (1-9) } & Motivation is comply regulation & \multirow{2}{*}{$58.5 \%$} & $0.97(0.05)$ \\
& Motivation is economic & & $0.77(0.23)$ \\
\hline & Strategy is reduce cost & & $-0.58(0.01)$ \\
Small (10-49) & Strategy is image & $64.0 \%$ & $0.63(<0.01)$ \\
& Risk of traumatic accidents & & $0.52(0.02)$ \\
\hline Medium (50-249) & Regulation is profitable & $72.9 \%$ & $1.00(0.02)$ \\
\hline Big $(>249)^{2}$ & -- & $100 \%$ & -- \\
\hline
\end{tabular}

${ }^{2}$ There was only one case without safety management system.

According to our study, the main reason for choosing an internal preventive model is having worker representation. But the rest of the predictors are related to each company size: for micro companies it is important to have safety as strategy and to view regulation as effective and not difficult; for small companies reasons 
are working in shifts and having more than one establishment; for medium companies it is important if their motivation is to improve company's image and economic; for big companies it is more important if they buy new machinery and considering regulation as profitable. Company's size as expected determines very different ways of understanding and facing safety issues.

On the other hand, safety management systems are more likely adopted by big and medium companies. Again, reasons to decide to implement safety management systems depend on company's size: for micro companies, main motivations is to comply with safety regulation and economic; small companies more likely implement a system if they have risk of accidents and their strategy is not reducing costs but improving company's image; medium companies need to find safety regulation as profitable.

Based on these results, specific research needs to be done in order to provide evidence about what facts or reasons can change manager's views about safety management and how to efficiently convince of the benefits of certain models.

\subsection{References}

Arocena P, Nuñez I, Villanueva M (2008). The impact of prevention measures and organizational factors on occupational injuries. Saf Sci 46(9): 1369-1384.

Bottani E, Monica L, Vignali G (2009). Safety management systems: Performance differences between adopters and non-adopters. Saf Sci 47(2): 155-162.

Cagno E, Micheli GJ, Perotti S (2011). Identification of OHS-related factors and interactions among those and OHS performance in SMEs. Saf Sci 4(29): 216-225.

Carrillo JA, Onieva L (2011). Performance of external health and safety services in andalusia: evaluation of outcome. In: Proceedings of the 9th Internacional Conference on Occupational Risk Prevention ORP2011. ISBN 978-84-934256-9-2

Carrillo JA, Onieva L (2012). Safety Management in Manufacturing and its Influence in Injury Rates: Evidences from Spanish National Safety Management Survey (2009). In: Industrial Engineering: Innovative Networks, Springer. ISBN 978-1-4471-2320-0.

Fernández-Muñiz B, Montes-Peón JM, Vázquez-Ordás CJ (2009). Relation between occupational safety management and firm performance. Saf Sci 47(7): 980-991.

Geldart S, Smith CA, Shannon HS, Lohfeld L (2010). Organizational practices and workplace health and safety: A cross-sectional study. Saf Sci 48(5): 562-569.

Huang, YH, Leamon TB, Courtney TK et al (2011). A comparison of workplace safety perceptions among financial decision-makers of medium- vs. large-size companies. Accid Anal Prev 43(1): 1-10.

Instituto Andaluz de Prevención de Riesgos Laborales (2011). I Encuesta sobre Gestión Preventiva de Empresas Andaluzas. ISBN 978-84-615-0020-8.

Øien K, Utne I, Herrera I (2011). Building Safety indicators: Part 1 - Theoretical foundation. Saf Sci 49(2): 148-161.

Sgorou E, Katsakiori P, Goutsos S et al (2010). Assessment of selected safety performance evaluation methods in regards. Saf Sci 48(8): 1019-1025.

Sorensen OH, Hasle P, Bach E (2007). Working in small enterprises - Is there a special risk? Safety Science 45(10): 1044-1059. 